\title{
Pemberian Enzim BS4 untuk Meningkatkan Performa Ayam KUB Masa Pertumbuhan
}

\section{(The Effect of BS4 Enzyme Supplementation on the Performance of Local Chicken- KUB during Growing Period)}

\author{
Sinurat AP, Hidayat C, Haryati T, Wardhani T, Sartika T \\ Balai Penelitian Ternak, PO Box 221, Ciawi, Bogor 16002 \\ arnoldsinurat@pertanian.go.id
}

\begin{abstract}
Enzyme has been used widely in livestock industry in order to improve efficiency on feed utilization (FCR). Indonesian Research Institute for Animal Production has been able to produce enzyme BS4 which has been proven can improve nutrient digestibilities of some feedstuffs and the FCR on improved breed chickens. A research was designed to evaluate the effectivity of the BS4 enzyme on the growing local-KUB chickens. Three dietary treatments, i.e., control diet (C); C + low level BS4; and C + high level BS4 enzyme were fed to KUB chickens from 1 day old to 12 weeks old. Each dietary treatment was fed to 5 replicates x 24 birds per replicate reared on litter cages. Observations were made on body weight at 1 day, 3, 6, 9 and 12 weeks of age, feed intake, FCR and the mortality during the experiment. All data were analysed statistically in order to show the effect of the treatments. Results showed that BS4 enzyme supplementation did not show significant effect on mortality, feed intake and body weight of KUB chickens. However, supplementation of BS4 enzyme improved the FCR overall period of experiment, although it was only statistically significant $(\mathrm{P}<0.05)$ for the period of $0-9$ weeks of age. It is concluded that supplementation of BS4 enzyme with dose $24 \mathrm{U} / \mathrm{kg}$ feed was effective to improve the FCR of the local-KUB chickens.
\end{abstract}

Key Words: BS4 Enzyme, Local Chickens KUB, FCR

\begin{abstract}
ABSTRAK
Enzim sudah banyak digunakan untuk meningkatan efisiensi penggunaan ransum dalam industri peternakan. Balai Penelitian Ternak sudah menghasilkan enzim BS4 yang dapat meningkatkan kecernaan gizi bahan pakan dan efisiensi penggunaan pakan (FCR) pada ayam ras. Penelitian dirancang untuk menguji efektivitas enzim BS4 yang ditambahkan ke dalam ransum ayam lokal KUB sedang tumbuh. Tiga perlakuan yang terdiri dari ransum kontrol $(\mathrm{K}) ; \mathrm{K}+$ enzim BS4 dosis rendah; dan K + enzim BS4 dosis tinggi diberikan pada ayam mulai umur sehari hingga 12 minggu. Ransum perlakuan diberikan ke-24 ekor ayam dengan lima ulangan yang dipelihara dalam kandang litter. Selama penelitian, dilakukan pengamatan terhadap bobot badan pada umur 1 hari, 3, 6, 9 dan 12 minggu, konsumsi pakan, FCR dan mortalitas ayam. Data dianalisis secara statistik untuk mengetahui pengaruh perlakuan. Hasil menunjukkan bahwa penambahan enzim BS4 secara statistik tidak nyata mempengaruhi mortalitas, konsumsi pakan dan bobot badan ayam KUB. Namun, suplementasi enzim BS4 dapat memperbaiki FCR secara keseluruhan, meskipun hanya nyata $(\mathrm{P}<0,05)$ secara statistik pada periode 0-9 minggu. Dari hasil penelitian ini disimpulkan bahwa suplementasi enzim BS4 dengan dosis $24 \mathrm{U} / \mathrm{kg}$ pakan cukup efektif untuk memperbaiki FCR pada ayam lokal KUB.
\end{abstract}

Kata Kunci: Enzim BS4, Ayam KUB, FCR 


\section{PENDAHULUAN}

Suplementasi enzim ke dalam pakan sebagai imbuhan pakan sudah banyak dilakukan oleh industri pakan maupun oleh peternak dengan tujuan meningkatkan efisiensi penggunaan pakan. Enzim adalah produk alami yang merupakan katalis biologis yang dapat memecah struktur molekul kompleks menjadi yang lebih sederhana, sehingga pakan atau bahan pakan yang mempunyai struktur molekul yang kompleks seperti polisakarida yang sangat sulit dicerna oleh ternak monogastrik meningkat kecernaannya. Peningkatan kecernaan gizi ini berakibat pada peningkatan efisiensi penggunaan pakan yang pada akhirnya dapat meghemat biaya pakan pada industri peternakan (Yadav \& Sah 2005; Costa et al. 2008). Selain untuk meningkatkan kecernaan gizi, saat ini enzim sudah digunakan sebagai pengganti imbuhan pakan antibiotik atau antibiotic growth promotor (AGP), seiring dengan pelarangan penggunaan AGP di banyak negara. Penambahan enzim pemecah serat dalam pakan menyebabkan kekentalan isi usus lebih encer sehingga perkembangbiakan bakteri patogen di dalam saluran lebih terbatas atau saluran pencernaan lebih sehat (Kiarie et al. 2013; Adeola \& Cowieson 2011).

Banyak jenis enzim yang diproduksi dan digunakan sebagai imbuhan pakan, dimana di Indonesia hampir semua masih merupakan produk impor. Efektivitas enzim sangat tergantung pada kesesuaian jenis enzim dengan target atau substrat, yaitu struktur molekul yang mau dipecah yang terdapat di dalam bahan pakan. Misalnya, xylanase efektif untuk memecah xylan sedangkan selulase efektif untuk memecah selulosa menjadi molekul karbohidrat yang lebih sederhana. Balai Penelitian Ternak (Balitnak) telah menghasilkan teknologi produksi enzim yang berasal dari pembiakan isolat lokal Eupenicilium javanicum dengan substrat padat. Enzim yang dihasilkan merupakan campuran enzim karbohidrase yang terdiri dari $\beta$-mannanase, cellulose, $\beta$-mannosidase, $\beta$-glucosidase, and $\alpha$-galactosidase (Purwadaria et al. 2003), yang dinamakan enzim BS4.

Beberapa pengujian dilaporkan bahwa enzim BS4 meningkatkan kecernaan gizi bahan pakan pada ayam seperti solid sawit (Sinurat et al. 2007; Pasaribu et al. 2009), bungkil inti sawit (Sinurat et al. 2013) serta meningkatkan efisiensi pakan pada ayam ras (Sinurat et al. 2008, 2011, 2016a; 2016b). Supplementasi enzim selama ini banyak dilaporkan pada ternak unggul dengan produktivitas tinggi dan seragam seperti ayam ras (petelur dan pedaging) serta pada ternak babi dan hampir tidak ada laporan pada ternak lokal yang pertumbuhan atau produksi telurnya rendah dan keragamannya tinggi seperti pada unggas lokal. Hal ini kemungkinan karena peningkatan performans teknis akibat penggunaan enzim tidak terlalu tinggi. Disamping itu, efektivitas enzim pada unggas sangat bervariasi tergantung pada jenis bahan pakan, aktivitas atau dosis enzim, sumber dan jenis enzim yang digunakan serta tingkat kandungan atau kecukupan gizi ransum (Choct 2006; Adeola \& Cowieson 2011). Dengan keragaman performans yang tinggi pada ternak lokal, kemungkinan peningkatan ini tidak terlihat secara nyata, namun diharapkan dapat memberi keuntungan secara ekonomi melalui pengurangan biaya produksi. Untuk mengetahui informasi tentang penggunaan enzim BS4 yang lebih luas atau agar aplikasi penggunaan enzim BS4 dapat dilakukan pada jenis pakan ternak yang lebih banyak, maka dilakukan pengujian pada ayam kampung unggul (KUB) selama periode pertumbuhan seperti dilaporkan dalam makalah ini.

\section{MATERI DAN METODE}

Penelitian ini dilakukam di kandang percobaan ayam di Balitnak-Ciawi. Sebanyak 360 ekor ayam KUB umur sehari tanpa dibedakan jenis kelaminnya (unsexed) dibagi secara acak ke dalam 15 kandang (unit) percobaan berukuran panjang $284 \mathrm{~cm}$ dan lebar 
$146 \mathrm{~cm}$ dengan masing-masing kandang diisi 24 ekor ayam. Ayam tersebut dipelihara di kandang litter beralaskan sekam padi dan diberi pemanas (lampu pijar) yang cukup hingga umur tiga minggu. Ayam diberi pakan dan air minum secara ad libitum selama penelitian. Jenis pakan yang diberikan adalah pakan ayam broiler starter komersil sebagai kontrol (K) pada umur 1 hingga 21 hari dengan kandungan gizi (sesuai label): Lemak kasar minimum $5 \%$, protein kasar 20-22\%, Ca 0,8-1,1\% dan P minimum 0,5\%. Pada umur 21 hingga 84 hari, ransum kontrol yang diberikan adalah campuran dari: Ransum broiler starter $59 \%$, bekatul 19\%, bungkil kedele 5\%, jagung giling $15 \%$ dan vitamin-mineral premix $2 \%$. Sebagai perlakuan, ransum K ditambahkan dengan enzim BS4 sebanyak dua tingkat, yaitu: Perlakuan 2 dengan 24 U/kg pakan atau 1,4 liter/ton pakan; dan Perlakuan 3 dengan 36 U/kg pakan atau 2,1 liter/ton pakan. Dengan demikian perlakuan yang diuji adalah sebagai berikut: (1) Ransum kontrol atau ransum yang biasa digunakan (RK) untuk ayam KUB; (2) $\mathrm{RK}+24 \mathrm{U} / \mathrm{kg}$ pakan enzim BS4; dan (3) RK + $36 \mathrm{U} / \mathrm{kg}$ pakan enzim BS4.

Untuk mengetahui pengaruh perlakuan terhadap performans ayam KUB, maka dilakukan pengamatan terhadap perkembangan bobot badan ayam setiap tiga minggu (umur 1 hari, 3, 6, 9 dan 12 minggu), perkembangan konsumsi pakan setiap minggu dan mortalitas ayam. Efisiensi penggunaan pakan (FCR) dihitung dengan membagi jumlah pakan yang dikonsumsi dengan bobot badan pada umur 0-3, 0-6, 0-9 dan 0-12 minggu. Karena ayam yang digunakan pada penelitian tidak dibedakan jenis kelaminnya, maka penimbangan ayam dengan jenis kelamin yang berbeda baru dilakukan setelah terlihat perbedaan fisik antara jantan dan betina, yaitu pada minggu ke- 6, 9 dan 12 .

Data yang diperoleh diuji secara statistik dengan analisis sidik ragam pola rancangan acak lengkap dengan 3 perlakuan dan 5 ulangan. Bila analisis sidik ragam menunjukkan beda nyata $(\mathrm{P}<0,05)$, maka perbedaan antara perlakuan diuji dengan uji Duncan.

\section{HASIL DAN PEMBAHASAN}

Hasil penelitian selengkapnya disajikan dalam Tabel 1, 2 dan 3. Secara umum, kondisi ayam selama penelitian cukup baik. Hal ini terlihat dari tingkat mortalitas yang sangat rendah, yaitu hanya $0,83-1,67 \%$ selama 12 minggu. Laporan sebelumnya menunjukkan bahwa rata-rata bobot badan ayam KUB umur 84 hari adalah sekitar 687-806 g/ekor (Iskandar et al. 2014), sedangkan rata-rata bobot badan ayam KUB dengan umur yang sama adalah 1.167-1.183 g/ekor (Tabel 3).

Perkembangan konsumsi ransum ayam KUB tiap minggu mulai umur 1 hingga 12 minggu, tidak nyata $(\mathrm{P}>0,05)$ dipengaruhi oleh suplementasi enzim dalam ransum (Tabel 1). Secara rata-rata, selama 12 minggu, konsumsi ransum ayam yang diberi enzim BS4 dengan dosis rendah (24 U/kg) maupun yang lebih tinggi $(36 \mathrm{U} / \mathrm{kg})$ tidak berbeda dengan kontrol padahal enzim BS4 telah dilaporkan dapat meningkatkan kecernaan gizi (bahan kering, energi dan protein) bahan pakan (Sinurat et al. 2007; 2013; Pasaribu et al. 2009). Jika hal ini terjadi, maka diharapkan bahwa penambahan enzim akan mengurangi konsumsi ransum karena jumlah gizi yang dibutuhkan untuk pertumbuhan sudah tercukupi dengan jumlah konsumsi yang lebih rendah. Terdapat kemungkinan zat gizi yang tersedia dalam ransum kontrol belum maksimal sehingga penambahan zat gizi yang tersedia dapat digunakan untuk meningkatkan pertumbuhan. Hasil penelitian sebelumnya juga menunjukkan bahwa suplementasi enzim BS4 dalam ransum ayam ras petelur (Sinurat et al. 2007; 2011; 2016a; 2016b) maupun dalam ransum ayam broiler, tidak mempengaruhi konsumsi pakan.

Bobot badan ayam KUB umur 1 hari, 3, 6, 9 dan 12 minggu, secara statistik juga tidak nyata $(\mathrm{P}>0,05)$ dipengaruhi oleh suplementasi enzim BS4 ke dalam pakan (Tabel 2). Namun, bobot badan ayam yang diberi enzim cenderung lebih berat dari ayam yang tidak 
diberi enzim (K) pada umur 3, 6, 9 dan 12 minggu. Kecenderungan ini juga terjadi pada ayam betina maupun ayam jantan pada umur 6, 9 dan 12 minggu. Pada umur tiga minggu, bobot badan ayam yang diberi enzim BS4 lebih tinggi 11-15 g/ekor dibandingkan dengan ayam kontrol. Rata-rata bobot badan ayam pada umur enam minggu lebih tinggi 7-10 g/ekor, pada umur sembilan minggu 7-30 g/ekor dan pada umur 12 minggu 14-16 g/ekor. Penelitian pada ayam broiler menunjukkan bahwa suplementasi enzim BS4 dalam bentuk cair maupun bentuk kering ke dalam ransum dapat meningkatkan bobot badan 4-5\% (Haryati et al. 2016).

Tabel 1. Konsumsi pakan ayam KUB dengan pemberian enzim BS4 selama 12 minggu

\begin{tabular}{lcccc}
\hline \hline \multirow{2}{*}{ Umur (minggu) } & Kontrol $(\mathrm{K})$ & $\mathrm{K}+\mathrm{BS} 4(24 \mathrm{U} / \mathrm{kg})$ & $\mathrm{K}+\mathrm{BS} 4(36 \mathrm{U} / \mathrm{kg})$ & \\
\cline { 2 - 3 } & ----- & Nilai P \\
\hline 1 & $7,1 \pm 0,3$ & $7,5 \pm 1,0$ & $7,7 \pm 0,7$ & 0,36 \\
2 & $15,5 \pm 0,7$ & $16,5 \pm 0,9$ & $16,3 \pm 0,9$ & 0,17 \\
3 & $27,3 \pm 2,3$ & $24,7 \pm 2,7$ & $24,8 \pm 0,9$ & 0,12 \\
4 & $31,9 \pm 3,6$ & $31,0 \pm 2,6$ & $30,4 \pm 2,3$ & 0,74 \\
5 & $38,1 \pm 3,9$ & $36,1 \pm 3,3$ & $39,6 \pm 5,0$ & 0,44 \\
6 & $49,4 \pm 1,6$ & $48,7 \pm 2,4$ & $51,1 \pm 2,0$ & 0,20 \\
7 & $48,6 \pm 2,0$ & $45,7 \pm 5,5$ & $50,2 \pm 1,9$ & 0,17 \\
8 & $64,9 \pm 1,4$ & $62,9 \pm 3,2$ & $66,2 \pm 1,8$ & 0,11 \\
9 & $68,5 \pm 1,6$ & $66,5 \pm 2,1$ & $68,7 \pm 2,1$ & 0,18 \\
10 & $69,3 \pm 1,9$ & $68,2 \pm 2,9$ & $69,4 \pm 0,9$ & 0,62 \\
11 & $86,6 \pm 3,7$ & $87,8 \pm 2,5$ & $86,8 \pm 1,6$ & 0,76 \\
12 & $93,3 \pm 2,6$ & $93,0 \pm 2,1$ & $90,6 \pm 3,4$ & 0,17 \\
\hline Rata-rata & $50,0 \pm 1,3$ & $49,0 \pm 1,9$ & $50,1 \pm 0,4$ & \\
\hline
\end{tabular}

Efisiensi penggunaan pakan atau FCR paling umum dilaporkan sebagai dampak penggunaan enzim dalam ransum unggas. Hal ini terjadi karena FCR merupakan hasil gabungan dari pengaruh enzim terhadap konsumsi ransum dan produksi (bobot badan atau produksi telur). Penurunan konsumsi ransum sedikit (meskipun tidak nyata) yang diikuti peningkatan produksi sedikit, dapat menyebabkan pengaruh terhadap FCR yang lebih nyata. Dalam penelitian ini, FCR dihitung pada periode 0-3, 0-6, 0-9 dan 0-12 minggu. Hasil penelitian ini menunjukkan bahwa FCR pada periode 0-3, 0-6 dan 0-12 minggu tidak nyata $(\mathrm{P}>0,05)$ dipengaruhi oleh suplementasi enzim BS4 dalam ransum. Nilai FCR pada periode $0-9$ minggu, nyata $(\mathrm{P}<0,05)$ dipengaruhi oleh suplementasi enzim dalam ransum (Tabel 2). Pada periode 0-9 minggu memperbaiki FCR 3,82-4,26\% (Tabel 2). Hasil penelitian sebelumnya menunjukkan bahwa suplementasi enzim BS4 dalam ransum ayam petelur memperbaiki efisiensi penggunaan pakan (FCR) sekitar 5,8-8,3\% (Sinurat et al. 2008; 2011; 2016a; 2016b) dan pada ayam broiler sekitar 8-9\% (Haryati et al. 2016).

Hasil ini menunjukkan bahwa pemberian enzim BS4 pada dosis rendah $(24 \mathrm{U} / \mathrm{kg})$ sudah mampu memperbaiki FCR dan pemberian enzim yang lebih banyak (36 U/kg) tidak lagi meningkatkan perbaikan FCR. Dosis ini juga merupakan dosis yang disarankan dalam ransum ayam petelur maupun ayam broiler berdasarkan hasil penelitian terdahulu. Dengan demikian, dosis $24 \mathrm{U} / \mathrm{kg}$ pakan disarankan untuk digunakan karena akan lebih ekonomis. Penambahan enzim ke dalam pakan umumnya mengikuti pola sigmoid atau tidak linear. Penambahan enzim akan memberi efek positif atau meningkat hingga mencapai puncak 
pada aktivitas atau dosis tertentu dan kemudian efeknya tidak bertambah atau mendatar pada penambahan enzim dengan dosis yang lebih tinggi. Hasil yang sama juga dilaporkan oleh Yuan et al. (2008).

Tabel 2. Perkembangan Bobot badan dan efisiensi penggunaan pakan (FCR) dan mortalitas ayam KUB yang diberi enzim BS4

\begin{tabular}{lcccc}
\hline \hline Parameter & Kontrol (K) & K + BS4 (24 U/kg) & K + BS4 (36 U/kg) & Nilai P \\
\hline Periode umur & Bobot badan (g/ekor) & & & \\
1 hari (DOC) & $29,2 \pm 1,2$ & $30,0 \pm 1,7$ & $30,0 \pm 1,7$ & 0,67 \\
3 minggu & $188 \pm 11,7$ & $199 \pm 13,4$ & $203 \pm 8,8$ & 0,16 \\
Gabungan 6 minggu & $450 \pm 19,8$ & $460 \pm 14,0$ & $457 \pm 27,8$ & 0,77 \\
Jantan 6 minggu & $490 \pm 22,1$ & $502 \pm 19,6$ & $502 \pm 26,0$ & 0,65 \\
Betina 6 minggu & $416 \pm 15,9$ & $426 \pm 16,2$ & $420 \pm 24,8$ & 0,71 \\
Gabungan 9 minggu & $776 \pm 29,6$ & $783 \pm 46,3$ & $806 \pm 25,1$ & 0,40 \\
Jantan 9 minggu & $853 \pm 37,2$ & $872 \pm 55,8$ & $900 \pm 29,3$ & 0,25 \\
Betina 9 minggu & $701 \pm 28,1$ & $714 \pm 32,1$ & $719 \pm 36,7$ & 0,60 \\
Gabungan 12 minggu & $1167 \pm 42$ & $1181 \pm 44$ & $1183 \pm 35$ & 0,53 \\
Jantan 12 minggu & $1323 \pm 60$ & $1337 \pm 64$ & $1349 \pm 38$ & 0,69 \\
Betina 12 minggu & $1021 \pm 17$ & $1054 \pm 26$ & $1034 \pm 29$ & 0,24 \\
Periode umur & Efisiensi penggunaan pakan atau FCR (g/g) & & \\
0-3 minggu & $1,859 \pm 0,138$ & $1,709 \pm 0,140$ & $1,681 \pm 0,040$ & 0,06 \\
0-6 minggu & $2,631 \pm 0,108$ & $2,503 \pm 0,139$ & $2,620 \pm 0,191$ & 0,36 \\
0-9 minggu & $3,193 \pm 0,076^{\mathrm{a}}$ & $3,057 \pm 0,093^{\mathrm{b}}$ & $3,071 \pm 0,065^{\mathrm{b}}$ & 0,04 \\
0-12 minggu & $3,524 \pm 0,127$ & $3,447 \pm 0,111$ & $3,467 \pm 0,090$ & 0,56 \\
Periode umur & Mortalitas $(\%)$ & & & 0,83 \\
0-12 minggu & 0,83 & 1,67 & & NA* \\
\hline
\end{tabular}

*NA: Tidak dilakukan analisis statistik karena nilai pengamatan terlalu kecil; Huruf yang berbeda pada baris yang sama, berbeda nyata $(\mathrm{P}<0,05)$

\section{KESIMPULAN}

Dari hasil penelitian ini disimpulkan bahwa suplementasi enzim BS4 ke dalam ransum ayam KUB selama masa pertumbuhan dapat meningkatkan efisiensi penggunaan pakan. Dosis efektif yang disarankan adalah $24 \mathrm{U} / \mathrm{kg}$ ransum.

\section{UCAPAN TERIMA KASIH}

Penulis menyampaikan ucapan terima kasih kepada Bapak Dedi dan Bapak Endang yang telah membantu dalam pemeliharaan ternak selama penelitian ini. 


\section{DAFTAR PUSTAKA}

Adeola O, Cowieson AJ. 2011. Board-invited review: Opportunities and challenges in using exogenous enzymes to improve nonruminant animal production. J Anim Sci. 89:3189-3218.

Costa FGP, Goulart CC, Figueiredo DF, Oliveira CFS, Silva JHV. 2008. Economic and environmental impact of using exogenous enzymes on poultry feeding. Int J Poult Sci. 7:311314.

Choct M, Kocher A, Waters DLE, Pettersson D, Ross G. 2006. A comparison of three xylanases on the nutritive value of two wheats for broiler chickens. Br J Nut. 92:53-61

Haryati, T, Purwadaria, Sinurat AP. 2016. Pengaruh pemberian enzim BS4 dalam bentuk cair atau kering terhadap performans ayam broiler. Laporan Penelitian. Bogor (Indonesia): Balitnak.

Kiarie E, Romero LF, Nyachoti CM. 2013. The role of added feed enzymes in promoting gut health in swine and poultry. Nut Res Rev. 26:71-88.

Iskandar S, Hidayat C, Cahyaningsih T. 2014, Pengaruh pemberian tansum pre-starter pada efisiensi kinerja ayam local KUB. JITV. 19: 203-209.

Pasaribu T, Sinurat AP, Purwadaria T, Ketaren PP. 2009. Peningkatan nilai gizi solid heavy phase sebagai pengganti jagung dalam pakan unggas. JITV. 14:167-176.

Purwadaria T, Haryati T, Frederick E, Tangendjaja B. 2003. Optimation of $\beta$-mannanase production on submerged culture of Eupenicillium javanicum as well as $\mathrm{pH}$ and temperature characterization. JITV. 8:46-54.

Sinurat AP, Purwadaria T, Bintang IAK, Pasaribu T. 2007. Peningkatan nilai gizi solid heavy phase dalam ransum unggas sebagai pengganti jagung. JITV. 12:87-95.

Sinurat AP, Purwadaria T, Bintang IAK, Pasaribu T, Manurung BP, Manurung N. 2008. Substitution of corn with enzymes treated palm oil sludge in laying hens diet. In: Proceedings XXIII World's Poult Sci Congress. Brisbane (Australia).

Sinurat, AP, Purwadaria T, Pasaribu T, Ketaren PP. 2011. Performances of laying hens fed with enzyme-supplemented palm kernel cake diets. Paper presented at APPC, Taipei, March 2011.

Sinurat AP, Purwadaria T, Pasaribu T. 2013. Peningkatan nilai gizi bungkil inti sawit dengan pengurangan cangkang dan penambahan enzim. JITV. 18:34-41.

Sinurat AP, Wibowo B, Purwadaria T, Haryati T. 2016a. Evaluation on the biological effectivity of BS4 enzymes in laying hens diet at commercial farms level. In: Marjuki, Ridlowi A, Jaya F, Susilowati T, Wittayakun S, Bottema DK, Alimon AR, Hsia LC, Thiruvenkadan AK, editors. Enhancing Synergistic Roles of Stakeholders for Development of Sustainable Livestock Production. Proceeding The 3rd APIS-ARCAP. Batu, 19-21 October 2016. Batu (Indonesia). Brawijaya University. p. 252-255.

Sinurat AP, Susana IWR, Purwadaria T, Haryati T, Hamid H, Kadiran. 2016b. Efektivitas enzim karbohidrase dan protease sebagai imbuhan pakan ayam broiler. Laporan Penelitian. Bogor (Indonesia): Balitnak.

Yadav JL, Sah RA. 2005. Supplementation of corn-soybean based broiler's diets with different levels of acid protease. J Inst Agric Anim Sci. 26:65-70.

Yuan J, Yao J, Yang F, Yang X, Wan X, Han J, Wang Y, Chen X, Liu Y, Zhou Z, Zhou N, Feng $X$. 2008. Effects of supplementing different levels of a commercial enzyme complex on performance, nutrient availability, enzyme activity and gut morphology of broilers. AsianAust J Anim Sci. 21:692-700. 


\section{DISKUSI}

\section{Pertanyaan}

1. Kenapa pada perlakuan enzim yang diberikan sedikit justru terjadi kematian?

2. Apakah enzim dapat dipengaruhi oleh suhu lingkungan?

\section{Jawaban}

1. Kematian sangat rendah bukan karena faktor enzim.

2. Enzim tidak dipengaruhi oleh suhu lingkungan. Karena enzim bekerja di dalam tubuh, kecuali kemungkinan suhu terlalu tinggi atau terlalu rendah (abnormal) dapat berpengaruh. 